\title{
Beneficial Microbes and Phosphorus Management Influence Dry Matter Partitioning and Accumulation in Wheat (Triticum aestivum L.) with and without Moisture Stress Condition
}

Amanullah*, Siddique Khan and Asim Muhammad

Department of Agronomy, The University of Agriculture Peshawar, Pakistan

\begin{abstract}
Field experiment was conducted to investigate the impact of beneficial microorganism (BMO) and phosphorus (P) application on dry matter (DM) accumulation and partitioning in spring wheat (Triticum aestivum L., cv. Siren) under full irrigated (no moisture stress) and limited irrigated (dryland or moisture stress) conditions. The experiment was conducted at the Agronomy Research Farm, The University of Agriculture Peshawar during winter 2012-13. The experiment under both moisture conditions was laid out in randomized complete block design using three replications. The results revealed that DM accumulation and partitioning into leaf, stem and spike was significantly higher in wheat under irrigated than dryland wheat. The treated plots (rest) had higher total DM accumulation and partitioned more DM into leaf, stem and spike than control at both anthesis and physiological maturity (PM). Application of P and BMO at the highest rates (90 kg P ha-1 and $30 \mathrm{~L} \mathrm{ha}^{-1}$, respectively) had accumulated more total DM and had partitioned more DM into leaf, stem and spike at the two growth stages. We found that under irrigated condition, increase in both $\mathrm{P}$ and BMO levels (90 kg P ha-1 and $30 \mathrm{~L} \mathrm{ha}^{-1}$, respectively) and under dryland condition the intermediate levels of both $\mathrm{P}$ and $\mathrm{BMO}$ (60 kg P ha-1 and $20 \mathrm{~L} \mathrm{ha}^{-1}$, respectively) had produced higher total DM and partitioned more DM into various parts at both anthesis and PM. The percent DM partitioning into leaf was more $(36 \%)$ than stem and spike (each $32 \%$ ) at anthesis stage; while at PM, more DM was partitioned into spike $(59 \%)$ than stem $(21 \%)$ and leaf $(20 \%)$. Increase in DM partitioning into spike under both irrigated and dryland wheat with proper $\mathrm{P}$ and BMO management showed positive relationship with grain yield that resulted in higher growers income in the study area.
\end{abstract}

Keywords: Beneficial microorganism; Phosphorus; Irrigation condition; Wheat; Dry matter partitioning; Growth stages

\section{Introduction}

Wheat (Tritium aestivum L.) is Pakistan key staple food crop among cereals which occupies about $37 \%$ of the cropped area and consumes about $45 \%$ of the total fertilizers utilized in the country. In Pakistan wheat is cultivated in both irrigated and dryland conditions and contributes $14.4 \%$ share in agriculture and $3 \%$ in gross domestic products. The total area of wheat in Pakistan during 2011-2012 was 8.649 million ha having 23.473 million tons production with average yield of $2714 \mathrm{~kg} \mathrm{ha}^{-1}$ [1]. Wheat average yield in the province of Khyber Pakthukhwa was $1550 \mathrm{~kg} \mathrm{ha}^{-1}$ in the same growing season which looks very compared with the national average yield [1]. The major factors for low productivity of wheat in Khyber Pakhtunkhwa are imbalanced application of fertilizers and water shortages especially under un-irrigated (dryland) condition. Increased production from the dryland areas is important if Pakistan is going to meet the needs of the country for food and other products. It is estimated that $12 \%$ of the total wheat production is harvested from rainfed areas, which can be increased several fold with proper management of production factors as the current management by the farmers is at a very basic level of technology [2]. Dryland agriculture is an important component of the national economy of Pakistan which currently contributes around 15 billion rupees annually.

The lack of optimum moisture and low soil fertility are the inherent problems in rainfed areas of Khyber Pakhtunkhwa [2]. The soils of Khyber Pakhtunkhwa have low organic matter content and less available $\mathrm{P}$ [2]. These soils contain high calcium carbonate with $\mathrm{pH}$ ranging from 7 to 9 . This high calcium activity coupled with high $\mathrm{pH}$ favors the formation of relatively insoluble dicalcium phosphate, hydroxyl apatite, carbonate apatite, and octo calcium phosphate. Soils with high fixation capacity have higher demand for P-fertilizer [3]. Phosphorus deficiency is invariably a common crop growth and yieldlimiting factor in unfertilized soils, especially in soils high in calcium carbonate which reduces P solubility [4]. Under these conditions only little of the applied $\mathrm{P}$ is available for crop plants which results in lower crop productivity. Under these soils application of beneficial microorganism (BMO) could increase $\mathrm{P}$ availability and thereby crop productivity. A diverse group of soil microflora was reported to be involved in solubilizing insoluble $\mathrm{P}$ complexes enabling plants to easily absorb P [5]. Many kinds of soil bacteria (bacillus, pseudomonas, rhizobium and enterobacter) and fungi (aspergilllus and penicillium) have the skill to change insoluble form of $\mathrm{P}$ in the soil into soluble form through releasing organic acids such as formic acids, propionic acids, acetic acids, fumaric acids, and succinic acids. These acids reduce the ${ }_{\mathrm{p}} \mathrm{H}$ and bring the dissolution of bound forms of phosphate [6]. As $\mathrm{P}$ is the major limiting factor for crop production in Khyber Pakhtunkhwa therefore combine application of BMO and $\mathrm{P}$ to these soils could increase $\mathrm{P}$ availability and crop productivity. However,

*Corresponding authors: Amanullah, Department of Agronomy, The University of Agriculture, Peshawar, Pakistan, Tel: +92 91 9216518; E-mail: amanullah@aup.edu.pk

Received October 30, 2015; Accepted November 07, 2015; Published November 14,2015

Citation: Amanullah, Khan S, Muhammad A (2015) Beneficial Microbes and Phosphorus Management Influence Dry Matter Partitioning and Accumulation in Wheat (Triticum aestivum L.) With and Without Moisture Stress Condition. J Microb Biochem Technol 7: 410-416. doi:10.4172/1948-5948.1000247

Copyright: (c) 2015 Amanullah, et al. This is an open-access article distributed under the terms of the Creative Commons Attribution License, which permits unrestricted use, distribution, and reproduction in any medium, provided the original author and source are credited. 
Citation: Amanullah, Khan S, Muhammad A (2015) Beneficial Microbes and Phosphorus Management Influence Dry Matter Partitioning and Accumulation in Wheat (Triticum aestivum L.) With and Without Moisture Stress Condition. J Microb Biochem Technol 7: 410-416. doi:10.4172/1948-5948.1000247

there is no research to investigate the interactive effects of $\mathrm{BMO} \times \mathrm{P}$ under irrigated and moisture stress conditions. This research work was therefore designed to study the interactive effects of BMO $\mathrm{x}$ P on dry matter partitioning of spring wheat under full irrigated (no moisture stress) and limited irrigated (moisture stress or dryland) conditions.

\section{Materials and Method}

\section{Experimentation}

Field experiment was conducted to investigate the effect of beneficial micro-organisms (BMO) $\left[10 \mathrm{~L} \mathrm{ha}^{-1}\right.$ (50\% less than the recommended rate), $20 \mathrm{~L} \mathrm{ha}^{-1}$ (recommended rate), and $30 \mathrm{~L} \mathrm{ha}^{-1}(50 \%$ higher than the recommended rate)] and phosphorus levels $(0,30$, 60 and $\left.90 \mathrm{~kg} \mathrm{P} \mathrm{ha}^{-1}\right)$ on dry matter partitioning and accumulation in spring wheat (Triticum aestivum L., cv. Siren-2010). The experiment was conducted under full irrigated condition (having no moisture stress) and limited irrigation (having moisture stress or dryland) conditions at the Agronomy Research Farm of The University of Agricultural Peshawar, during winter 2012-13. The experiment under full irrigated condition received a total of five irrigations [ $1^{\text {st }}$ for seedbed preparation, $2^{\text {nd }} 10$ days after sowing for beneficial microorganism and $2^{\text {nd }}$ dose of $\mathrm{N}$ application (26 $6^{\text {th }}$ November $), 3^{\text {rd }}$ 60 days after sowing ( $15^{\text {th }}$ January), $4^{\text {th }}$ after anthesis $\left(30^{\text {th }}\right.$ March $)$ and $5^{\text {th }}$ at grain fill duration ( $13^{\text {th }}$ April)]. The experiment under limited irrigated condition (moisture stress, dryland condition) received only two irrigations $\left[1^{\text {st }}\right.$ irrigation for seedbed preparation before sowing and $2^{\text {nd }}$ irrigation at 10 days after sowing for $\mathrm{BM}$ and $2^{\text {nd }}$ dose of $\mathrm{N}$ application $\left(26^{\text {th }}\right.$ November $)$. The BMO was applied in the form of "Bioaab" obtained from the Cheinar Agro Trade Batkhela (Malakand), Khyber Pakhtunkhwa, while phosphorus was used in the form of triple super phosphate $\left(46 \% \mathrm{P}_{2} \mathrm{O}_{5}\right)$. The BMO 'Bioaab' was prepared by mixing one liter of Bioaab+one kgmolasses +10 or 20 or 30 liters of water and sprayed in their respective plots in standing water at 10 days after sowing.

\section{Experimental design and plot size}

The experiment was laid out in randomized complete block design using three replications under both full irrigated (no moisture stress) and limited irrigated (moisture stress) conditions. Each replication consisted of 10 treatments including three BMO levels $\mathrm{x}$ three $\mathrm{P}$ levels (9 treatments) +one control treatment (no BMO and $\mathrm{P}$ applied). A sub-plot size of $4 \mathrm{~m}$ by $2.40 \mathrm{~m}$, having 8 rows, $4 \mathrm{~m}$ long and $30 \mathrm{~cm}$ apart was used. A uniform dose of $120 \mathrm{~kg} \mathrm{~N} \mathrm{ha}^{-1}$ as urea was applied to all treatments in two equal splits, i.e., half each at sowing and first irrigation (10 days after sowing).

\section{Site description}

The experimental farm is located at $34.018^{\circ} \mathrm{N}$ latitude, $71.358^{\circ} \mathrm{E}$ longitude at an altitude of $350 \mathrm{~m}$ above sea level in Peshawar valley. Peshawar is located about $1600 \mathrm{~km}$ north of the Indian Ocean and has a continental type of climate. Soil of the farm is clay loam, low in organic matter $(0.87 \%)$, phosphorus $\left(6.57 \mathrm{mg} \mathrm{kg}^{-1}\right)$, potassium (121 $\left.\mathrm{mg} \mathrm{kg}^{-1}\right)$, is alkaline ( $\mathrm{pH} 8.2$ ) and calcareous in nature [7]. The area has a continental type of climate and is generally semiarid with mean annual rainfall ranging between 300 and $500 \mathrm{~mm}$, of which 60-70\%, called the monsoon rains, occurs during summer (JulySeptember) and the remaining $30-40 \%$ occurs in winter [7].

\section{Weather data of experimental period}

The average rainfall data of wheat growing season (2012-13) indicates that there was no rainfall during the whole months of January and May. The rainfall was less in November $2012(0.4 \mathrm{~mm})$, April $2013(7.2 \mathrm{~mm})$ and March $2013(9.5 \mathrm{~mm})$. The rainfall was little higher in December $2012(34 \mathrm{~mm})$, while maximum rainfall $(166 \mathrm{~mm})$ occurred in February 2013.

\section{Data recording and handling}

Data were recorded on dry matter (DM) partitioning into leaf, stem, spike and total DM accumulation $\left(\mathrm{gm}^{-2}\right)$ at the time of anthesis and physiological maturity (PM).

\section{Statistical analysis}

Data were statistically analyzed combined over irrigation condition [8] and means were compared using LSD test $(\mathrm{p} \leq 0.05)$.

\section{Experimental Results}

\section{Leaf dry matter at anthesis}

Leaf dry matter (LDM) at anthesis of wheat was significantly affected by irrigation condition (IC), phosphorus (P) and beneficial microorganism (BMO), the interactions BMO $\mathrm{x}$ P, IC $\mathrm{x}$ P and IC $\mathrm{x} P \mathrm{x}$ $\mathrm{BMO}$ had significant effect on LDM, while the interaction IC $x$ BMO had no significant effect on LDM (Table 1). The rest of the treated plots had significantly higher LDM $\left(251.8 \mathrm{gm}^{-2}\right)$ than control $\left(210.7 \mathrm{gm}^{-2}\right)$. The highest LDM $\left(259.4 \mathrm{gm}^{-2}\right)$ was obtained from the full irrigated field as compared with the limited irrigated field $\left(243.0 \mathrm{gm}^{-2}\right)$. Among the $\mathrm{P}$ levels, the highest LDM $\left(262.7 \mathrm{gm}^{-2}\right)$ was recorded for the plots treated with the highest P level $\left(90 \mathrm{~kg} \mathrm{ha}^{-1}\right)$, followed by $252.2 \mathrm{gm}^{-2}(60 \mathrm{~kg} \mathrm{P}$ ha

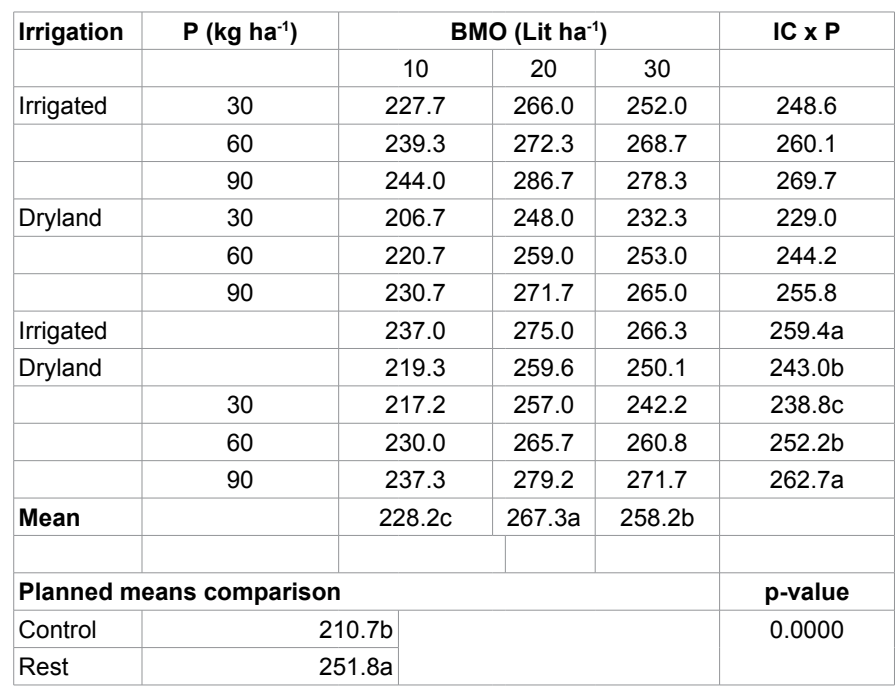

Means of the same category followed by different letters are significantly different from each other using $L S D$ test $(P \leq 0.05)$.

\begin{tabular}{|c|c|c|}
\hline \multicolumn{3}{|c|}{ Least Significant Difference $(\mathbf{p} \leq \mathbf{0 . 0 5})$} \\
\hline $\mathrm{BMO}$ & $=$ & 1.5 \\
\hline $\mathrm{P}$ & $=$ & 1.5 \\
\hline $\mathrm{BMO} \times \mathrm{P}$ & $=$ & $* *$ \\
\hline $\mathrm{IC} \times \mathrm{BMO}$ & $=$ & $\mathrm{ns}$ \\
\hline $\mathrm{IC} \times \mathrm{P}$ & $=$ & $* *$ \\
\hline $\mathrm{IC} \times \mathrm{BMO} \times \mathrm{P}$ & $=$ & $* *$ \\
\hline
\end{tabular}

Where: ns stands for non-significant data, while ** and * indicates significant at 1 and $5 \%$ level of probability, respectively using LSD test $(P \leq 0.05)$.

Table 1: Dry matter partitioning into leaf $\left(\mathrm{g} \mathrm{m}^{-2}\right)$ at anthesis of wheat (Triticum aestivum $\mathrm{L}$.) as affected by phosphorous $(\mathrm{P})$ and beneficial microorganism (BMO) under irrigated and dryland conditions (IC). 
Citation: Amanullah, Khan S, Muhammad A (2015) Beneficial Microbes and Phosphorus Management Influence Dry Matter Partitioning and Accumulation in Wheat (Triticum aestivum L.) With and Without Moisture Stress Condition. J Microb Biochem Technol 7: 410-416. doi:10.4172/1948-5948.1000247

$\left.{ }^{1}\right)$, while the lowest $\operatorname{LDM}\left(238.8 \mathrm{gm}^{-2}\right)$ was obtained from the plots that received $30 \mathrm{~kg} \mathrm{P} \mathrm{ha}^{-1}$. Among the BMO levels, the highest LDM (267.3 $\mathrm{gm}^{-2}$ ) was recorded for the plots treated with $20 \mathrm{~L} \mathrm{BMO} \mathrm{ha}^{-1}$, followed by $258.2 \mathrm{gm}^{-2}\left(30 \mathrm{~L} \mathrm{ha}^{-1}\right)$, while the lowest LDM $\left(228.2 \mathrm{gm}^{-2}\right)$ was noted for the plots that received $10 \mathrm{~L} \mathrm{BMO} \mathrm{ha-1}$. The interaction between BMO x P indicated that at all P levels the LDM was increased when $\mathrm{BMO}$ level was increased up to $20 \mathrm{~L} \mathrm{BMO} \mathrm{ha}^{-1}$ and further increase in BMO level decreased LDM. The interaction between IC $\mathrm{x} P$ indicated that increase in $\mathrm{P}$ level increased LDM under both full and limited irrigation conditions. The interaction among IC $\mathrm{x}$ BMO $\mathrm{x}$ P indicated that the intermediate BMO level $\left(20 \mathrm{~L} \mathrm{ha}^{-1}\right)$ produced the highest LDM at all $\mathrm{P}$ levels in both full irrigated and limited irrigation conditions.

\section{Stem dry matter at anthesis}

Stem dry matter (STDM) of wheat at anthesis stage was significantly affected by IC, P and BMO levels. The interactions BMO x P and IC $\mathrm{x}$ $\mathrm{P}$ had no significant effect, while IC $\mathrm{x}$ BMO and IC $\mathrm{x}$ P $\mathrm{x}$ BMO had significant effect on STDM (Table 2). The rest of the plots had higher STDM $\left(227.0 \mathrm{gm}^{-2}\right)$ than control $\left(199.7 \mathrm{gm}^{-2}\right)$. The highest STDM $\left(237.0 \mathrm{gm}^{-2}\right)$ was obtained from the full irrigated field as compared with the limited irrigated field $\left(214.1 \mathrm{gm}^{-2}\right)$. Among the P levels, the highest STDM $\left(233.1 \mathrm{gm}^{-2}\right)$ was recorded for the plots treated with the highest P level $\left(90 \mathrm{~kg} \mathrm{ha}^{-1}\right)$, followed by $226.1 \mathrm{gm}^{-2}\left(60 \mathrm{~kg} \mathrm{P} \mathrm{ha}^{-1}\right)$, while the lowest STDM $\left(217.6 \mathrm{gm}^{-2}\right)$ was noted with $30 \mathrm{~kg} \mathrm{P} \mathrm{ha}^{-1}$. Among the BMO levels, the highest STDM $\left(234.4 \mathrm{gm}^{-2}\right)$ was recorded for the plots treated with $20 \mathrm{~L} \mathrm{BMO} \mathrm{ha}^{-1}$, followed by $225.9 \mathrm{gm}^{-2}\left(30 \mathrm{~L} \mathrm{ha}^{-1}\right)$, while the lowest STDM $\left(216.4 \mathrm{gm}^{-2}\right)$ was obtained from the plots that received 10 $\mathrm{L} \mathrm{BMO} \mathrm{ha}{ }^{-1}$. The interaction between IC $\mathrm{x}$ BMO revealed that irrigated plots at all BMO levels produced higher STDM than limited irrigation

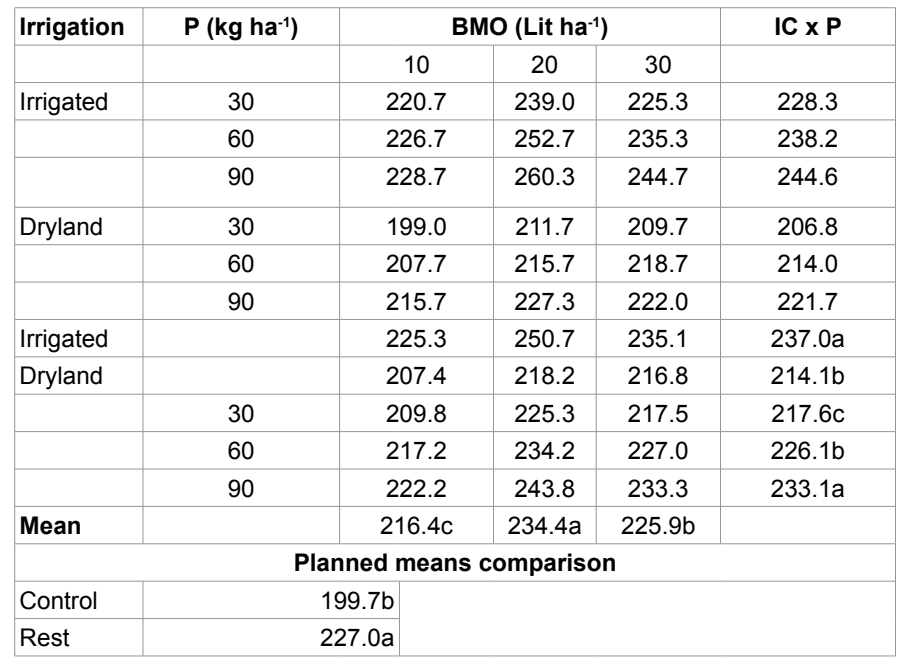

Means of the same category followed by different letters are significantly differen from each other using $L S D$ test $(P \leq 0.05)$.

\begin{tabular}{|c|c|c|}
\hline \multicolumn{3}{|c|}{ Least Significant Difference $(\mathbf{p} \leq \mathbf{0 . 0 5})$} \\
\hline $\mathrm{BMO}$ & $\mathbf{2}$ & 1.9 \\
\hline $\mathrm{P}$ & $\mathbf{1}$ & 1.9 \\
\hline $\mathrm{BMO} \times \mathrm{P}$ & $=$ & $\mathrm{ns}$ \\
\hline $\mathrm{IC} \times \mathrm{BMO}$ & $=$ & ** \\
\hline $\mathrm{IC} \times \mathrm{P}$ & $=$ & $\mathrm{ns}$ \\
\hline $\mathrm{IC} \times \mathrm{BMO} \times \mathrm{P}$ & $* *$ \\
\hline
\end{tabular}

Where: ns stands for non-significant data, while ** indicates significant at $1 \%$ level of probability using LSD test $(P \leq 0.05)$.

Table 2: Dry matter partitioning into stem $\left(\mathrm{g} \mathrm{m}^{-2}\right)$ at anthesis of wheat (Triticum aestivum $\mathrm{L}$.) as affected by phosphorous $(\mathrm{P})$ and beneficial microorganism (BMO) under irrigated and dryland conditions (IC). condition. The interaction among IC $x$ BMO $x$ P indicated that the intermediate BMO level $\left(20 \mathrm{~L} \mathrm{ha}^{-1}\right)$ produced highest STDM at all $\mathrm{P}$ levels in both full irrigated and limited irrigation conditions.

\section{Spike dry matter at anthesis}

Spike dry matter (SPDM) at anthesis was significantly affected by $\mathrm{IC}, \mathrm{P}$ and $\mathrm{BMO}$ levels, and all the interactions i.e. $\mathrm{BMO} \times \mathrm{P}, \mathrm{IC} \times \mathrm{BMO}$, $\mathrm{IC} \times \mathrm{P}$ and $\mathrm{IC} \times \mathrm{BMO} \times \mathrm{P}$ had significant effects on SPDM (Table 3 ). The rest of the treated plots had higher SPDM $\left(218.9 \mathrm{gm}^{-2}\right)$ than control $\left(197.0 \mathrm{gm}^{-2}\right)$. The highest SPDM $\left(227.3 \mathrm{gm}^{-2}\right)$ was obtained from the full irrigated field as compared with the limited irrigated field $(212.0$ $\left.\mathrm{gm}^{-2}\right)$. Among the P levels, the highest SPDM $\left(226.8 \mathrm{gm}^{-2}\right)$ was recorded for the plots treated with the highest P level $\left(90 \mathrm{~kg} \mathrm{ha}^{-1}\right)$, followed by $220.2 \mathrm{gm}^{-2}\left(60 \mathrm{~kg} \mathrm{P} \mathrm{ha}^{-1}\right)$, while the lowest SDM $\left(112.1 \mathrm{gm}^{-2}\right)$ was obtained from the plots that received $30 \mathrm{~kg} \mathrm{P} \mathrm{ha}^{-1}$. Among the BMO levels, the highest SPDM $\left(228.5 \mathrm{gm}^{-2}\right)$ was recorded for the plots treated with 20 $\mathrm{L} \mathrm{BMO} \mathrm{ha}{ }^{-1}$, followed by $220.5 \mathrm{gm}^{-2}\left(30 \mathrm{~L} \mathrm{ha}^{-1}\right)$, while the lowest SDM $\left(210.0 \mathrm{gm}^{-2}\right)$ was obtained from the plots that received $10 \mathrm{~L} \mathrm{BMO}$ $\mathrm{ha}^{-1}$. The interaction between $\mathrm{BMO} \times \mathrm{P}$ indicated that at all $\mathrm{P}$ levels the SPDM was increased when BMO level was increased up to $20 \mathrm{~L}$ $\mathrm{BMO} \mathrm{ha}^{-1}$ and further increase in BMO level decreased SPDM. The interaction between $\mathrm{IC} \times \mathrm{BMO}$ revealed that irrigated plots at all $\mathrm{BMO}$ levels produced higher SDM than limited irrigation condition. The interaction between IC $\mathrm{x}$ P indicated that increase in $\mathrm{P}$ level up to the highest level $\left(90 \mathrm{~kg} \mathrm{P} \mathrm{ha}^{-1}\right)$ increased SPDM under both full and limited irrigation conditions. The interaction among $\mathrm{IC} \times \mathrm{BMO} \times \mathrm{P}$ indicated that the intermediate BMO level $20 \mathrm{~L} \mathrm{ha}^{-1}$ produced highest SPDM at all $\mathrm{P}$ levels in both full irrigated and limited irrigation conditions.

\begin{tabular}{|c|c|c|c|c|c|}
\hline \multirow[t]{2}{*}{ Irrigation } & \multirow[t]{2}{*}{$P\left(k g h^{-1}\right)$} & \multicolumn{3}{|c|}{ BMO (Lit ha-1) } & \multirow[t]{2}{*}{ IC $\times P$} \\
\hline & & 10 & 20 & 30 & \\
\hline \multirow[t]{3}{*}{ Irrigated } & 30 & 209.3 & 228.0 & 222.3 & 219.9 \\
\hline & 60 & 219.0 & 235.0 & 230.0 & 228.0 \\
\hline & 90 & 224.0 & 243.7 & 234.7 & 234.1 \\
\hline \multirow[t]{3}{*}{ Dryland } & 30 & 193.7 & 213.7 & 205.3 & 204.2 \\
\hline & 60 & 203.0 & 221.0 & 213.0 & 212.3 \\
\hline & 90 & 211.0 & 229.7 & 217.7 & 219.4 \\
\hline Irrigated & & 217.4 & 235.6 & 229.0 & $227.3 a$ \\
\hline \multirow[t]{4}{*}{ Dryland } & & 202.6 & 221.4 & 212.0 & $212.0 \mathrm{~b}$ \\
\hline & 30 & 201.5 & 220.8 & 213.8 & $212.1 \mathrm{c}$ \\
\hline & 60 & 211.0 & 228.0 & 221.5 & $220.2 b$ \\
\hline & 90 & 217.5 & 236.7 & 226.2 & $226.8 a$ \\
\hline Mean & & $210.0 c$ & $228.5 a$ & $220.5 b$ & \\
\hline \multicolumn{5}{|c|}{ Planned means comparison } & \\
\hline Control & \multicolumn{4}{|c|}{$197.0 \mathrm{~b}$} & \\
\hline Rest & \multicolumn{4}{|c|}{$218.9 a$} & \\
\hline
\end{tabular}

Means of the same category followed by different letters are significantly different from each other using $L S D$ test $(P \leq 0.05)$.

\begin{tabular}{|c|c|c|}
\hline \multicolumn{3}{|c|}{ Least Significant Difference $(\mathbf{p} \leq \mathbf{0 . 0 5})$} \\
\hline $\mathrm{BMO}$ & $=$ & 1.35 \\
\hline $\mathrm{P}$ & $=$ & 1.35 \\
\hline $\mathrm{BMO} \times \mathrm{P}$ & $=$ & $* *$ \\
\hline $\mathrm{IC} \times \mathrm{BMO}$ & $=$ & $* *$ \\
\hline $\mathrm{IC} \times \mathrm{P}$ & $=$ & $* *$ \\
\hline $\mathrm{IC} \times \mathrm{BMO} \times \mathrm{P}$ & $=$ & $* *$ \\
\hline
\end{tabular}

Where: ns stands for non-significant data, while ${ }^{* *}$ indicates significant at $1 \%$ level of probability using LSD test $(P \leq 0.05)$.

Table 3: Dry matter partitioning into spike $\left(\mathrm{g} \mathrm{m}^{-2}\right)$ at anthesis of wheat (Triticum aestivum $\mathrm{L}$.) as affected by phosphorous $(\mathrm{P})$ and beneficial microorganism (BMO) under irrigated and dryland conditions (IC). 
Citation: Amanullah, Khan S, Muhammad A (2015) Beneficial Microbes and Phosphorus Management Influence Dry Matter Partitioning and Accumulation in Wheat (Triticum aestivum L.) With and Without Moisture Stress Condition. J Microb Biochem Technol 7: 410-416. doi:10.4172/1948-5948.1000247

\section{Total dry matter at anthesis}

Total dry matter (TDM) of wheat at anthesis was significantly affected IC, P and BMO levels, and all interactions (Table 4). The rest (treated plots) had significantly higher TDM $\left(697.7 \mathrm{gm}^{-2}\right)$ than control $\left(607.3 \mathrm{gm}^{-2}\right)$. The highest TDM $\left(723.8 \mathrm{gm}^{-2}\right)$ was recorded for the full irrigation condition as compared with the limited irrigation condition $\left(669.1 \mathrm{gm}^{-2}\right)$. Among the P levels, the highest TDM $\left(722.6 \mathrm{gm}^{-2}\right)$ was recorded for the plots treated with the highest P level $\left(90 \mathrm{~kg} \mathrm{ha}^{-1}\right)$, followed by $698.4 \mathrm{gm}^{-2}\left(60 \mathrm{~kg} \mathrm{P} \mathrm{ha}^{-1}\right)$, while the lowest TDM (668.4 $\mathrm{gm}^{-2}$ ) was obtained from the plots that received $30 \mathrm{~kg} \mathrm{P} \mathrm{ha}^{-1}$. Among the BMO levels, the highest TDM $\left(730.2 \mathrm{gm}^{-2}\right)$ was recorded for the plots treated with $20 \mathrm{~L} \mathrm{BMO} \mathrm{ha-1}$, followed by $704.7 \mathrm{gm}^{-2}\left(30 \mathrm{~L} \mathrm{ha}^{-1}\right)$, while the lowest TDM $\left(654.6 \mathrm{gm}^{-2}\right)$ was obtained from the plots that received $10 \mathrm{~L} \mathrm{BMO} \mathrm{ha}^{-1}$. The interaction between $\mathrm{BMO} \times \mathrm{P}$ indicated that at all $\mathrm{P}$ levels the TDM increased when BMO level was increased up to $20 \mathrm{~L} \mathrm{ha}^{-1}$ and further increase in BMO level decreased TDM. The interaction between IC $\mathrm{x}$ BMO revealed that irrigated plots at all BMO levels produced higher TDM than limited irrigation condition. The interaction between IC $\mathrm{x}$ P indicated that increase in $\mathrm{P}$ level up to the highest level $\left(90 \mathrm{~kg} \mathrm{P} \mathrm{ha}^{-1}\right)$ increased TDM under both full and limited irrigation conditions. The interaction among IC $\mathrm{x}$ BMO $\mathrm{x} P$ indicated that the intermediate BMO level $\left(20 \mathrm{~L} \mathrm{ha}^{-1}\right)$ in combination with 90 $\mathrm{kg} \mathrm{P} \mathrm{ha}^{-1}$ produced higher TDM under full and limited irrigation conditions, but the increase in TDM was more under full than limited irrigation condition.

\section{Leaf dry matter at physiological maturity}

Leaf dry matter LDM $\left(\mathrm{gm}^{-2}\right)$ at physiological maturity (PM)

\begin{tabular}{|c|c|c|c|c|c|}
\hline \multirow[t]{2}{*}{ Irrigation } & \multirow[t]{2}{*}{$P\left(\mathbf{k g ~ h a}^{-1}\right)$} & \multicolumn{3}{|c|}{ BMO (Lit ha-1) } & \multirow[t]{2}{*}{ IC $\times P$} \\
\hline & & 10 & 20 & 30 & \\
\hline \multirow[t]{3}{*}{ Irrigated } & 30 & 657.7 & 733.0 & 699.7 & 696.8 \\
\hline & 60 & 685.0 & 760.0 & 734.0 & 726.3 \\
\hline & 90 & 696.7 & 790.7 & 757.7 & 748.3 \\
\hline \multirow[t]{3}{*}{ Dryland } & 30 & 599.3 & 673.3 & 647.3 & 640.0 \\
\hline & 60 & 631.3 & 695.7 & 684.7 & 670.6 \\
\hline & 90 & 657.3 & 728.7 & 704.7 & 696.9 \\
\hline Irrigated & & 679.8 & 761.2 & 730.4 & $723.8 a$ \\
\hline \multirow[t]{4}{*}{ Dryland } & & 629.3 & 699.2 & 678.9 & $669.1 \mathrm{~b}$ \\
\hline & 30 & 628.5 & 703.2 & 673.5 & $668.4 \mathrm{c}$ \\
\hline & 60 & 658.2 & 727.8 & 709.3 & $698.4 b$ \\
\hline & 90 & 677.0 & 759.7 & 731.2 & $722.6 a$ \\
\hline Mean & & $654.6 c$ & $730.2 a$ & $704.7 b$ & \\
\hline \multicolumn{6}{|c|}{ Planned means comparison } \\
\hline Control & \multicolumn{2}{|c|}{$607.3 b$} & & & \\
\hline Rest & \multicolumn{2}{|c|}{$697.7 a$} & & & \\
\hline
\end{tabular}

Means of the same category followed by different letters are significantly differen from each other using $L S D$ test $(P \leq 0.05)$.

\begin{tabular}{|c|c|c|}
\hline \multicolumn{3}{|c|}{ Least Significant Difference $(\mathbf{p} \leq \mathbf{0 . 0 5})$} \\
\hline $\mathrm{BMO}$ & $\mathbf{2}$ & 2.86 \\
\hline $\mathrm{P}$ & $\mathbf{=}$ & 2.86 \\
\hline $\mathrm{BMO} \times \mathrm{P}$ & $=$ & $* *$ \\
\hline $\mathrm{IC} \times \mathrm{BMO}$ & $=$ & $* *$ \\
\hline $\mathrm{IC} \times \mathrm{P}$ & $=$ & $* *$ \\
\hline $\mathrm{IC} \times \mathrm{BMO} \times \mathrm{P}$ & & $* *$ \\
\hline
\end{tabular}

Where: ns stands for non-significant data, while ** indicates significant at $1 \%$ level of probability using LSD test $(P \leq 0.05)$.

Table 4: Total dry matter accumulation $\left(\mathrm{g} \mathrm{m}^{-2}\right)$ at anthesis of wheat (Triticum aestivum $\mathrm{L}$.) as affected by phosphorous $(\mathrm{P})$ and beneficial microorganism (BMO) under irrigated and dryland conditions (IC). of wheat was significantly affected by IC, P and BMO levels. The interactions $\mathrm{BMO} \times \mathrm{P}$ and IC $\mathrm{x}$ P had significant effect, while IC $\mathrm{x}$ BMO and IC $x$ BMO $x$ P had no significant effect on LDM (Table 5). The rest (treated plots) had higher LDM (198.5 $\left.\mathrm{gm}^{-2}\right)$ than control (180.5 gm $\left.{ }^{2}\right)$. The highest LDM $\left(204.7 \mathrm{gm}^{-2}\right)$ was obtained for the full irrigation condition as compared with the limited irrigation condition (191.1 $\left.\mathrm{gm}^{-2}\right)$. Among the P levels, the highest LDM $\left(204.5 \mathrm{gm}^{-2}\right)$ was recorded for the plots treated with the highest P level $\left(90 \mathrm{~kg} \mathrm{ha}^{-1}\right)$, followed by $199.7 \mathrm{gm}^{-2}\left(60 \mathrm{~kg} \mathrm{P} \mathrm{ha}^{-1}\right)$, while the lowest LDM $\left(189.4 \mathrm{gm}^{-2}\right)$ was obtained from the plots that received $30 \mathrm{~kg} \mathrm{P} \mathrm{ha}^{-1}$. Among the BMO levels, the highest LDM $\left(204.6 \mathrm{gm}^{-2}\right)$ was recorded for the plots treated with $30 \mathrm{~L} \mathrm{BMO} \mathrm{ha}^{-1}$, followed by $199.3 \mathrm{gm}^{-2}\left(20 \mathrm{~L} \mathrm{ha}^{-1}\right)$, while the lowest LDM $\left(189.7 \mathrm{gm}^{-2}\right)$ was obtained from the plots that received $10 \mathrm{~L}$ BMO $\mathrm{ha}^{-1}$. The interaction between BMO $\mathrm{P}$ indicated that increase in BMO and P levels increased LDM of wheat. The interaction between IC $x \mathrm{P}$ indicated that increase in P level increased LDM under both full and limited irrigation conditions, however, the increase was more for full than limited irrigation condition.

\section{Stem dry matter at physiological maturity}

The STDM of wheat at PM was significantly affected IC, $\mathrm{P}$ and BMO levels. The interactions BMO $x$ P, IC $x$ P and IC $x$ P x BMO had no significant effect, while the interaction IC $\mathrm{x}$ BMO had significant effect on STDM (Table 6). The rest plots had higher STDM $\left(214.0 \mathrm{gm}^{-2}\right)$ than control $\left(187.3 \mathrm{gm}^{-2}\right)$. The highest STDM $\left(223.6 \mathrm{gm}^{-2}\right)$ was obtained from the full irrigation condition as compared with the limited irrigation condition $\left(202.1 \mathrm{gm}^{-2}\right)$. Among the P levels, the highest STDM $\left(218.8 \mathrm{gm}^{-2}\right)$ was recorded for the plots treated with the highest

\begin{tabular}{|c|c|c|c|c|c|}
\hline \multirow[t]{2}{*}{ Irrigation } & \multirow[t]{2}{*}{$P\left(\mathbf{k g ~ h a}^{-1}\right)$} & \multicolumn{3}{|c|}{ BMO (Lit ha-1) } & \multirow[t]{2}{*}{ IC $\times P$} \\
\hline & & 10 & 20 & 30 & \\
\hline \multirow[t]{3}{*}{ Irrigated } & 30 & 190.3 & 197.7 & 201.7 & 196.6 \\
\hline & 60 & 198.7 & 206.7 & 211.0 & 205.4 \\
\hline & 90 & 203.7 & 213.7 & 218.7 & 212.0 \\
\hline \multirow[t]{3}{*}{ Dryland } & 30 & 175.0 & 184.0 & 187.7 & 182.2 \\
\hline & 60 & 183.7 & 195.7 & 202.7 & 194.0 \\
\hline & 90 & 187.0 & 198.0 & 206.0 & 197.0 \\
\hline Irrigated & & 197.6 & 206.0 & 210.4 & $204.7 a$ \\
\hline \multirow[t]{4}{*}{ Dryland } & & 181.9 & 192.6 & 198.8 & 191.1b \\
\hline & 30 & 182.7 & 190.8 & 194.7 & $189.4 \mathrm{c}$ \\
\hline & 60 & 191.2 & 201.2 & 206.8 & $199.7 b$ \\
\hline & 90 & 195.3 & 205.8 & 212.3 & $204.5 a$ \\
\hline Mean & & 189.7c & $199.3 b$ & $204.6 a$ & \\
\hline \multicolumn{5}{|c|}{ Planned means comparison } & \\
\hline Control & \multicolumn{4}{|c|}{$180.5 b$} & \\
\hline Rest & \multicolumn{4}{|c|}{$198.5 a$} & \\
\hline
\end{tabular}

Means of the same category followed by different letters are significantly different from each other using $L S D$ test $(P \leq 0.05)$.

\begin{tabular}{|c|c|c|}
\hline \multicolumn{3}{|c|}{ Least Significant Difference $(\mathbf{p} \leq \mathbf{0 . 0 5})$} \\
\hline $\mathrm{BMO}$ & $=$ & 1.91 \\
\hline $\mathrm{P}$ & $=$ & 1.91 \\
\hline $\mathrm{BMO} \times \mathrm{P}$ & $=$ & $* *$ \\
\hline $\mathrm{IC} \times \mathrm{BMO}$ & $=$ & $\mathrm{ns}$ \\
\hline $\mathrm{IC} \times \mathrm{P}$ & $=$ & $*$ \\
\hline $\mathrm{IC} \times \mathrm{BMO} \times \mathrm{P}$ & $=$ & $\mathrm{ns}$ \\
\hline
\end{tabular}

Where: ns stands for non-significant data, while ** and * indicates significant at 1 and $5 \%$ level of probability, respectively using LSD test $(P \leq 0.05)$.

Table 5: Dry matter partitioning into leaf $\left(\mathrm{g} \mathrm{m}^{-2}\right)$ at physiological maturity of wheat (Triticum aestivum $\mathrm{L}$.) as affected by phosphorous $(\mathrm{P})$ and beneficial microorganism (BMO) under irrigated and dryland conditions (IC). 
Citation: Amanullah, Khan S, Muhammad A (2015) Beneficial Microbes and Phosphorus Management Influence Dry Matter Partitioning and Accumulation in Wheat (Triticum aestivum L.) With and Without Moisture Stress Condition. J Microb Biochem Technol 7: 410-416. doi:10.4172/1948-5948.1000247

\begin{tabular}{|c|c|c|c|c|c|}
\hline \multirow[t]{2}{*}{ Irrigation } & \multirow[t]{2}{*}{$P\left(\right.$ kg ha $\left.^{-1}\right)$} & \multicolumn{3}{|c|}{ BMO (Lit ha-1) } & \multirow[t]{2}{*}{ IC $\times \mathrm{P}$} \\
\hline & & 10 & 20 & 30 & \\
\hline \multirow[t]{3}{*}{ Irrigated } & 30 & 208.7 & 219.3 & 225.3 & 217.8 \\
\hline & 60 & 217.3 & 225.7 & 231.7 & 224.9 \\
\hline & 90 & 216.3 & 230.3 & 237.3 & 228.0 \\
\hline \multirow[t]{3}{*}{ Dryland } & 30 & 181.3 & 197.0 & 204.3 & 194.2 \\
\hline & 60 & 195.0 & 204.3 & 208.3 & 202.6 \\
\hline & 90 & 201.0 & 210.0 & 218.0 & 209.7 \\
\hline Irrigated & & 214.1 & 225.1 & 231.4 & $223.6 \mathrm{a}$ \\
\hline \multirow[t]{4}{*}{ Dryland } & & 192.4 & 203.8 & 210.2 & $202.1 \mathrm{~b}$ \\
\hline & 30 & 195.0 & 208.2 & 214.8 & $206.0 \mathrm{c}$ \\
\hline & 60 & 206.2 & 215.0 & 220.0 & $213.7 \mathrm{~b}$ \\
\hline & 90 & 208.7 & 220.2 & 227.7 & $218.8 \mathrm{a}$ \\
\hline Mean & & $203.3 c$ & $214.4 b$ & $220.8 a$ & \\
\hline \multicolumn{5}{|c|}{ Planned means comparison } & \\
\hline Control & \multicolumn{4}{|c|}{$187.3 \mathrm{~b}$} & \\
\hline Rest & \multicolumn{4}{|c|}{$214.0 a$} & \\
\hline
\end{tabular}

\begin{tabular}{|c|c|c|c|c|c|}
\hline \multirow[t]{2}{*}{ Irrigation } & \multirow[t]{2}{*}{$P\left(\mathbf{k g ~ h a}^{-1}\right)$} & \multicolumn{3}{|c|}{ BMO (Lit ha-1) } & \multirow[t]{2}{*}{ IC $\times \mathrm{P}$} \\
\hline & & 10 & 20 & 30 & \\
\hline \multirow[t]{3}{*}{ Irrigated } & 30 & 590.0 & 603.0 & 610.0 & 601.0 \\
\hline & 60 & 601.0 & 614.0 & 625.7 & 613.6 \\
\hline & 90 & 612.7 & 625.3 & 632.0 & 623.3 \\
\hline \multirow[t]{3}{*}{ Dryland } & 30 & 549.7 & 569.0 & 576.0 & 564.9 \\
\hline & 60 & 566.7 & 580.0 & 590.3 & 579.0 \\
\hline & 90 & 579.0 & 595.0 & 601.7 & 591.9 \\
\hline Irrigated & & 601.2 & 614.1 & 622.6 & $612.6 a$ \\
\hline \multirow[t]{4}{*}{ Dryland } & & 565.1 & 581.3 & 589.3 & $578.6 \mathrm{~b}$ \\
\hline & 30 & 569.8 & 586.0 & 593.0 & $582.9 \mathrm{c}$ \\
\hline & 60 & 583.8 & 597.0 & 608.0 & $596.3 \mathrm{~b}$ \\
\hline & 90 & 595.8 & 610.2 & 616.8 & $607.6 a$ \\
\hline Mean & & $583.2 \mathrm{c}$ & $597.7 \mathrm{~b}$ & $605.9 a$ & \\
\hline \multicolumn{5}{|c|}{ Planned means comparison } & p-value \\
\hline Control & \multicolumn{4}{|c|}{$553.2 \mathrm{~b}$} & \\
\hline Rest & \multicolumn{4}{|c|}{$597.8 \mathrm{a}$} & \\
\hline
\end{tabular}

Means of the same category followed by different letters are significantly differen from each other using $L S D$ test $(P \leq 0.05)$.

\begin{tabular}{|l|l|c|}
\hline \multicolumn{2}{|l|}{ Least Significant Difference $(\mathbf{p} \mathbf{0} \mathbf{0 . 0 5})$} & \\
\hline $\mathrm{BMO}$ & $\mathbf{2}$ & 2.7 \\
\hline $\mathrm{P}$ & $=$ & 2.7 \\
\hline $\mathrm{BMO} \times \mathrm{P}$ & $=$ & $\mathrm{ns}$ \\
\hline $\mathrm{IC} \times \mathrm{BMO}$ & $=$ & * \\
\hline $\mathrm{IC} \times \mathrm{P}$ & $=$ & $\mathrm{ns}$ \\
\hline $\mathrm{IC} \times \mathrm{BMO} \times \mathrm{P}$ & $\mathrm{ns}$ \\
\hline
\end{tabular}

Where: ns stands for non-significant data, while ** indicates significant at $1 \%$ level of probability using LSD test $(P \leq 0.05)$.

Table 6: Dry matter partitioning into stem $\left(\mathrm{g} \mathrm{m}^{-2}\right)$ at physiological maturity of wheat (Triticum aestivum $\mathrm{L}$.) as affected by phosphorous $(\mathrm{P})$ and beneficial microorganism (BMO) under irrigated and dryland conditions (IC).

P level (90 kg ha $\left.{ }^{-1}\right)$, followed by $213.7 \mathrm{gm}^{-2}\left(60 \mathrm{~kg} \mathrm{P} \mathrm{ha}^{-1}\right)$, while the lowest STDM $\left(206.0 \mathrm{gm}^{-2}\right)$ was obtained from the plots that received 30 $\mathrm{kg} \mathrm{P} \mathrm{ha}{ }^{-1}$. Among the BMO levels, the highest STDM $\left(220.8 \mathrm{gm}^{-2}\right)$ was recorded for the plots treated with $30 \mathrm{~L} \mathrm{BMO} \mathrm{ha}^{-1}$, followed by 214.4 $\mathrm{gm}^{-2}\left(20 \mathrm{~L} \mathrm{ha}^{-1}\right)$, while the lowest STDM $\left(203.3 \mathrm{gm}^{-2}\right)$ was obtained from the plots that received $10 \mathrm{~L} \mathrm{BMO} \mathrm{ha}^{-1}$.The interaction between IC $\mathrm{x}$ $\mathrm{BMO}$ revealed that irrigated plots at all BMO levels produced higher STDM than limited irrigation condition, however, the increase under both irrigation conditions was more when $\mathrm{MB}$ level was increased.

\section{Spike dry matter at physiological maturity}

The SPDM at PM of wheat was significantly affected by IC, P and BMO levels. The interactions BMO x P, IC x P and IC x P x BMO had no significant effect, while the interaction of IC $\mathrm{x}$ BMO had significant effect on SPDM (Table 7). The treated plots had significantly higher $\operatorname{SPDM}\left(597.8 \mathrm{gm}^{-2}\right)$ than control $\left(553.2 \mathrm{gm}^{-2}\right)$. The highest SPDM $(612.6$ $\mathrm{gm}^{-2}$ ) was obtained from the full irrigation condition as compared with the limited irrigation condition $\left(578.6 \mathrm{gm}^{-2}\right)$. Among the P levels, the highest SPDM $\left(607.6 \mathrm{gm}^{-2}\right)$ was recorded for the plots treated with the highest P level $\left(90 \mathrm{~kg} \mathrm{ha}^{-1}\right)$, followed by $596.3 \mathrm{gm}^{-2}\left(60 \mathrm{~kg} \mathrm{P} \mathrm{ha}^{-1}\right)$, while the lowest SPDM $\left(582.9 \mathrm{gm}^{-2}\right)$ was obtained from the plots that received $30 \mathrm{~kg} \mathrm{P} \mathrm{ha}^{-1}$. Among the BMO levels, the highest SPDM $\left(605.9 \mathrm{gm}^{-2}\right)$ was recorded for the plots treated with $30 \mathrm{~L} \mathrm{BMO} \mathrm{ha}^{-1}$, followed by $597.7 \mathrm{gm}^{-2}\left(20 \mathrm{~L} \mathrm{ha}^{-1}\right)$, while the lowest SPDM $\left(583.2 \mathrm{gm}^{-2}\right)$ was obtained from the plots that received $10 \mathrm{~L} \mathrm{BMO} \mathrm{ha}^{-1}$. The interaction between IC $x$ BMO revealed increase in BMO level increase SPDM under both irrigation conditions, however, the irrigated plots at all BMO levels produced higher SPDM than limited irrigation condition.

Means of the same category followed by different letters are significantly different from each other using $L S D$ test $(P \leq 0.05)$.

\begin{tabular}{|c|c|c|}
\hline \multicolumn{3}{|c|}{ Least Significant Difference $(\mathbf{p} \leq \mathbf{0 . 0 5})$} \\
\hline BMO & $=$ & 2.03 \\
\hline $\mathrm{P}$ & $=$ & 2.03 \\
\hline $\mathrm{BMO} \times \mathrm{P}$ & $=$ & $\mathrm{ns}$ \\
\hline $\mathrm{IC} \times \mathrm{BMO}$ & $=$ & $* *$ \\
\hline $\mathrm{IC} \times \mathrm{P}$ & $=$ & $\mathrm{ns}$ \\
\hline $\mathrm{IC} \times \mathrm{BMO} \times \mathrm{P}$ & $\mathrm{ns}$ \\
\hline
\end{tabular}

Where: ns stands for non-significant data, while ${ }^{* *}$ indicates significant at $1 \%$ level of probability using LSD test $(\mathrm{P} \leq 0.05)$.

Table 7: Dry matter partitioning into spike $\left(\mathrm{g} \mathrm{m}^{-2}\right)$ at physiological maturity of wheat (Triticum aestivum $\mathrm{L}$.) as affected by phosphorous $(\mathrm{P})$ and beneficial microorganism (BMO) under irrigated and dryland conditions (IC).

\section{Total dry matter at physiological maturity}

The TDM of wheat at PM was significantly affected by IC, $\mathrm{P}$ and $\mathrm{BMO}$ levels (Table 8). The interactions between $\mathrm{BMO} \times \mathrm{P}$ and IC $\mathrm{x}$ $\mathrm{BMO}$ had significant effect, while the interactions IC $\mathrm{x} P$ and IC $\mathrm{x} P$ $\mathrm{x}$ BMO had no significant effect on TDM. The rest (treated plots) had significantly higher TDM (1010.3 $\left.\mathrm{gm}^{-2}\right)$ than control $\left(921.0 \mathrm{gm}^{-2}\right)$. The highest TDM $\left(1040.9 \mathrm{gm}^{-2}\right)$ was obtained from the full irrigation condition as compared with the limited irrigation condition $(971.8 \mathrm{gm}$ $\left.{ }^{2}\right)$. Among the P levels, the highest TDM $\left(1030.9 \mathrm{gm}^{-2}\right)$ was recorded for the plots treated with the highest P level $\left(90 \mathrm{~kg} \mathrm{ha}^{-1}\right)$, followed by 1009.7 $\mathrm{gm}^{-2}\left(60 \mathrm{~kg} \mathrm{P} \mathrm{ha}^{-1}\right)$, while the lowest TDM $\left(978.3 \mathrm{gm}^{-2}\right)$ was obtained from the plots that received $30 \mathrm{~kg} \mathrm{P} \mathrm{ha}^{-1}$. Among the BMO levels, the highest TDM $\left(1031.4 \mathrm{gm}^{-2}\right)$ was recorded for the plots treated with 30 $\mathrm{L} \mathrm{BMO} \mathrm{ha}{ }^{-1}$, followed by $1011.4 \mathrm{gm}^{-2}\left(20 \mathrm{~L} \mathrm{ha}^{-1}\right)$, while the lowest TDM $\left(976.2 \mathrm{gm}^{-2}\right)$ was obtained from the plots that received $10 \mathrm{~L} \mathrm{BMO} \mathrm{ha}^{-1}$. The interaction between $\mathrm{BMO} \times \mathrm{P}$ indicated that increase in both $\mathrm{BMO}$ and $\mathrm{P}$ levels increased TDM in wheat.

\section{Discussion}

The results revealed that the treat plots (rest) accumulated more total dry matter (DM) and partioned more DM into leaf, stem and spike at both anthesis and physiological maturity (PM). Total DM accumulation and partitioning is very important because it had positive relationship with absolute growth rate, crop growth rate, net assimilation rate and water use efficiency [8]. Our results from the same study suggested that the rest (treated plots) produced taller plants, more leaves per plant and higher single leaf area (data not 
Citation: Amanullah, Khan S, Muhammad A (2015) Beneficial Microbes and Phosphorus Management Influence Dry Matter Partitioning and Accumulation in Wheat (Triticum aestivum L.) With and Without Moisture Stress Condition. J Microb Biochem Technol 7: 410-416. doi:10.4172/1948-5948.1000247

\begin{tabular}{|c|c|c|c|c|c|}
\hline \multirow[t]{2}{*}{ Irrigation } & \multirow[t]{2}{*}{$\mathbf{P}\left(\mathbf{k g ~ h a} \mathbf{~}^{-1}\right)$} & \multicolumn{3}{|c|}{ BMO (Lit ha-1) } & \multirow[t]{2}{*}{ IC $\times \mathrm{P}$} \\
\hline & & 10 & 20 & 30 & \\
\hline \multirow[t]{3}{*}{ Irrigated } & 30 & 989.0 & 1020.0 & 1037.0 & 1015.3 \\
\hline & 60 & 1017.0 & 1046.3 & 1068.3 & 1043.9 \\
\hline & 90 & 1032.7 & 1069.3 & 1088.0 & 1063.3 \\
\hline \multirow[t]{3}{*}{ Dryland } & 30 & 906.0 & 950.0 & 968.0 & 941.3 \\
\hline & 60 & 945.3 & 980.0 & 1001.3 & 975.6 \\
\hline & 90 & 967.0 & 1003.0 & 1025.7 & 998.6 \\
\hline Irrigated & & 1012.9 & 1045.2 & 1064.4 & $1040.9 a$ \\
\hline \multirow[t]{4}{*}{ Dryland } & & 939.4 & 977.7 & 998.3 & $971.8 \mathrm{~b}$ \\
\hline & 30 & 947.5 & 985.0 & 1002.5 & $978.3 \mathrm{c}$ \\
\hline & 60 & 981.2 & 1013.2 & 1034.8 & $1009.7 \mathrm{~b}$ \\
\hline & 90 & 999.8 & 1036.2 & 1056.8 & $1030.9 a$ \\
\hline Mean & & $976.2 \mathrm{c}$ & 1011.4b & $1031.4 a$ & \\
\hline \multicolumn{6}{|c|}{ Planned means comparison } \\
\hline Control & $921.0 \mathrm{~b}$ & & & & \\
\hline Rest & $1010.3 a$ & & & & \\
\hline
\end{tabular}

Means of the same category followed by different letters are significantly different from each other using $L S D$ test $(P \leq 0.05)$.

\begin{tabular}{|c|c|c|}
\hline \multicolumn{3}{|c|}{ Least Significant Difference $(\mathbf{p} \leq \mathbf{0 . 0 5})$} \\
\hline BMO & $=$ & 3.57 \\
\hline $\mathrm{P}$ & $=$ & 3.57 \\
\hline $\mathrm{BMO} \times \mathrm{P}$ & $=$ & $* *$ \\
\hline $\mathrm{IC} \times \mathrm{BMO}$ & $=$ & $\mathrm{ns}$ \\
\hline $\mathrm{IC} \times \mathrm{P}$ & $=$ & $\mathrm{ns}$ \\
\hline $\mathrm{IC} \times \mathrm{BMO} \times \mathrm{P}$ & & \\
\hline
\end{tabular}

Where: $n$ s stands for non-significant data, while ${ }^{* *}$ indicates significant at $1 \%$ level of probability using LSD test $(P \leq 0.05)$

Table 8: Total dry matter accumulation $\left(\mathrm{g} \mathrm{m}^{-2}\right)$ at physiological maturity of wheat (Triticum aestivum $\mathrm{L}$.) as affected by phosphorous $(\mathrm{P})$ and beneficial microorganism (BMO) under irrigated and dryland conditions (IC).

published), and higher yield and yield components [9] than control plots. The improved growth and higher yield under treated plots than control plots indicating the importance of $\mathrm{P} \times \mathrm{BMO}$ application under calcareous soils in semiarid condition. The results further revealed that the full irrigated plots accumulated more total DM and portioned more DM into leaf, stem and spike at both anthesis and PM. The less DM accumulation and partitioning under limited irrigation conditions probably may be due to lower photosynthetic rate because low water availability. According to Sinaki et al., photosynthesis and DM accumulation reduced under moisture stress condition [10]. The results of this experiment [9] revealed that number of spikes $\mathrm{m}^{-2}$ grains per spike in wheat increased under full irrigation condition and lower number of both parameters was recorded under limited irrigation condition. The increase in number of spikes $\mathrm{m}^{-2}$ and grains per spike under full irrigation condition probably may be the major cause to increase total DM accumulation and partitioning into various parts. Radmehr et al. observed more number of spikes $\mathrm{m}^{-2}$ under irrigated than un-irrigation condition [11]. Misbah reported higher number of grains spike ${ }^{-1}$ under irrigation condition because of the availability of water at critical growth stages improve growth and development of wheat than moisture stress condition [12]. Kabir et al. reported that full irrigation improved economic yield because of improved crop growth, yield components and also it enabled crop to intercept maximum photosynthetic radiation over limited irrigated plants [13]. The results also revealed that the increase in $\mathrm{P}$ level accumulated more total DM and portioned more DM into leaf, stem and spike at both anthesis and PM. A large amount of DM was accumulated in response to the application of the highest rate of $\left(90 \mathrm{~kg} \mathrm{P} \mathrm{ha}^{-1}\right)$. The increase in total

DM accumulation with increase in $\mathrm{P}$ probably may be due $\mathrm{P}$ being the components of ATP might have contributed to a higher photosynthetic rate, abundant vegetative growth and assimilates formation and partitioning [14]. The results of this experiment revealed that number of spikes $\mathrm{m}^{-2}$ and grains per spike in wheat increased when $P$ was applied at the highest rate $90 \mathrm{~kg} \mathrm{P} \mathrm{ha}^{-1}[9]$. The increase in number of spikes $\mathrm{m}^{-2}$ and grains per spike with increase in $\mathrm{P}$ level probably may be the major cause for increasing total DM accumulation and its partitioning into various plant parts. Memon et al. and Rahim et al. reported that grains per spike in wheat increased with increase in P level $[15,16]$. The lack of optimum moisture and low soil fertility are the inherent problems in rainfed areas of Khyber Pakhtunkhwa [2]. Phosphorus and $\mathrm{N}$ deficient plants usually have more dry matter partitioning to roots than shoots, probably as a result of higher export rates of photosynthates to roots [17]. The results also revealed that application of $\mathrm{BMO}$ at the two higher levels (20 and $30 \mathrm{~L} \mathrm{ha}^{-1}$ ) accumulated more total DM and partioned more DM into leaf, stem and spike at both anthesis and PM. Our results from this study suggested that that the increase in BMO level increased spikes $\mathrm{m}^{-2}$ and grains per spike that resulted in higher total DM accumulation and partitioning into different parts of wheat [9]. Because BMO application increases the availability of plant nutrients especially $\mathrm{P}$ availability that results in better plant growth and higher production $[5,6,18]$. Dobblaere et al. assessed the inoculation effect of $\mathrm{BMO}$ on growth of spring wheat and observed that inoculated wheat plants had better growth, more number of grains spike ${ }^{-1}$ and grain yield [19]. The average data (Table 9) revealed that at anthesis percent DM partitioning into leaf was more (36\%) than stem and spike (each $32 \%)$, while at PM more DM was portioned into spike (59\%) than stem (21\%) and leaf (20\%). At anthesis more assimilates were partitioned to into leaf because during this stage there was no or less sink present, but at PM the highest assimilates were translocated into the spike. These results are similar to those of Singh et al. who stated that during anthesis stages most of the DM accumulated in stem and leaves [2025]. But duringmaturity stage, greater assimilates was translocated to spike for grain formation. Amanullah and Stewart observed differences in DM partitioning into various plant parts of oats at 30,60 and 90 days after emergence [8].

\section{Conclusion}

It was concluded from the experiment that under full irrigated (no moisture stress) condition wheat had more DM accumulation and partitioning into various plant parts than dryland (moisture stress) condition. Increase in both $\mathrm{P}$ and $\mathrm{BMO}$ levels $\left(90 \mathrm{~kg} \mathrm{P} \mathrm{ha}^{-1}\right.$ and 30 $\mathrm{L} \mathrm{ha}^{-1}$, respectively) had positive effects on total DM accumulation,

\begin{tabular}{|c|c|c|c|c|c|c|c|c|}
\hline \multirow{2}{*}{\begin{tabular}{|l|} 
Treatment \\
BMO $\left(\right.$ L ha $\left.^{-1}\right)$ \\
\end{tabular}} & \multicolumn{4}{|c|}{ Anthesis } & \multicolumn{4}{|c|}{ Physiological maturity } \\
\hline & Leaf & Stem & Spike & Total & Leaf & Stem & Spike & Total \\
\hline 10 & 35 & 33 & 32 & 100 & 19 & 21 & 60 & 100 \\
\hline 20 & 37 & 32 & 31 & 100 & 20 & 21 & 59 & 100 \\
\hline 30 & 37 & 32 & 31 & 100 & 20 & 21 & 59 & 100 \\
\hline \multicolumn{9}{|l|}{ Phosphorus (kg ha-1) } \\
\hline 30 & 36 & 33 & 32 & 100 & 19 & 21 & 60 & 100 \\
\hline 60 & 36 & 32 & 32 & 100 & 20 & 21 & 59 & 100 \\
\hline 90 & 36 & 32 & 31 & 100 & 20 & 21 & 59 & 100 \\
\hline \multicolumn{9}{|l|}{ Irrigation condition } \\
\hline Full & 36 & 33 & 31 & 100 & 20 & 21 & 59 & 100 \\
\hline Limited & 36 & 32 & 32 & 100 & 20 & 21 & 60 & 100 \\
\hline Average treatments & 36 & 32 & 32 & 100 & 20 & 21 & 59 & 100 \\
\hline
\end{tabular}

Table 9: Percent dry matter partioning into leaf, stem and spikes at anthesis and physiological maturity of wheat as affected by beneficial microorganism (BMO), phosphorus $(P)$ under full and limited irrigation conditions. 
Citation: Amanullah, Khan S, Muhammad A (2015) Beneficial Microbes and Phosphorus Management Influence Dry Matter Partitioning and Accumulation in Wheat (Triticum aestivum L.) With and Without Moisture Stress Condition. J Microb Biochem Technol 7: 410-416. doi:10.4172/1948-5948.1000247

DM partitioning and yield when there was no moisture stress. Under moisture stress, the intermediate levels of both $\mathrm{P}$ and $\mathrm{BMO}(60 \mathrm{~kg} \mathrm{P}$ $\mathrm{ha}^{-1}$ and $20 \mathrm{~L} \mathrm{ha}^{-1}$, respectively) was found more beneficial in terms of higher DM accumulation, DM partitioning and yield. The percent DM partitioning was greater into leaf at anthesis (leaf $>$ stem $=$ spike) and greater into spike (spike $>$ stem $>$ leaf) at physiological maturity.

\section{References}

1. Mainfa (2012) Ministry of Food and Agriculture Statitics of Pakistan. Pakistan Bureau of Statistics 1-3.

2. Amanullah A, Khan Z, Hussain D (2010) Performance of wheat cultivars sown at different seeding rates under moisture stress conditions. Archives of Agronomy and Soil Science 56: 99-105.

3. Amanullah, Zakirullah M, Khalil SK (2010) Timing and Rate of Phosphorus Application Influence Maize

4. Phenology, Yield and Profitability in Northwest Pakistan. International Journal of Plant Production 4: 1735-8043.

5. Ibrikci H, Ryan J, Ulger AC, Buyuk G, Cakir B, et al. (2005) Maintenance of $\mathrm{P}$ fertilizer and residual $\mathrm{P}$ effect on corn production. Nigerian Journal of Soil Science 2: 279-286.

6. Tripura CB, Sashidhar B, Podile AR (2005) Transgenic mineral phosphate solubilizing bacteria for improved agricultural productivity, I.K. International Publishing House Pvt Ltd, New Delhi, India.

7. Walpola BC, Yoon MH (2012) Prospectus of phosphate solubilizing microorganisms and phosphorus availability in agricultural soils: A review. African Journal of Microbiology Research 6: 6600-6605.

8. Amanullah RA, Khalil SK (2009) Effects of plant density and $\mathrm{N}$ on phenology and yield of maize. Journal of Plant Nutrition 32: 246-260.

9. Amanullah, Stewart BA (2013) Dry matter partitioning, growth analysis and water use efficiency response of oats (Avena sativa $\mathrm{L}$ ) to excessive nitrogen and phosphorus application. Journal of Agriculture Science and Technology 15: $479-489$

10. Amanullah A, Khan A (2015) Phosphorus and compost management influence maize (Zea mays)

11. productivity under semiarid condition with and without phosphate solubilizing bacteria. Front Plant Sci 6: 1083.

12. Sinaki JM, Heravan EM, Rad AHS, Noormohamadi, et al. (2007) The effects of water deficit during growth stages of canola (Brassica napus L). AmercanEurasian Journal of Agriculture and Environmental Science 2: 417-422.

13. Radmehar M (1997) Effect heat stress on physiology of growth and development of wheat. Ferdosi Mashhad University Press.

14. Misbah EAE (2009) Effect of irrigation regimes and foliar spraying potassium on yield, yield components water use efficiency of wheat in sandy soils. World Journal of Agriculture Science 5: 662-669.

15. Kabir KAR, Haque MA (2009) Effect of seed rate and irrigation level on the performance of winter wheat $\mathrm{cv}$. Gourab. Journal of the Bangladesh Agriculture University 7: 47-52.

16. Lu N, Barber SA (1995) Phosphorus uptake rate and growth characteristics of wheat roots. Journal of Plant Nutrition 8: 449-456.

17. Memon MY, Khan P, Imtiaz M, Shah JA, Deper N (2011) Response of candidate wheat variety nia-8/7 to different levels/ratios of nitrogen and phosphorous. Pakistan Journal of Botany 43: 1959-1963.

18. Rahim A, Ranjha AM, Rahamtullah EA, Waraich (2010) Effect of phosphorus application and irrigation scheduling on wheat yield and phosphorus use efficiency. Soil and Environment 29: 15-22.

19. Fagaria NK, Baligar VC, Clark RB (2006) Root Architecture. In: Physiology of Crop Production". The Haworth Press, Binghamton, New York, USA.

20. Soylu SA, Topal B, Sade N, Akgun S, Gezgin (2004) Yield and yield attributes of durum wheat genotypes as affected by BMO application in calcareous soils. An evaluation of major Turkish genotypes for BMO efficiency. Journal of Plant Nutrition 27: 1077-1106.

21. Dobbelaere S, Croonenborghs A, Thys A, Ptacek D, Okon Y (2002) Effect of inoculation with beneficial microorganisms Azospirillum brasilense and $A$. irakense strains on development and nitrogen uptake of spring wheat and grain maize. Biology and Fertility of Soils 36: 284-297.

22. Singh S, Dindwal AS, Bhattoo MS (2004) Dry matter accumulation, partitioning and translocation in late sown wheat under different irrigation levels. Annals of Agriculture and Biology Research 2: 151-154.

23. Sinaki JM, Heravan EM, Rad AHS, Noormohamadi, ZG Ghasem (2007) The effects of water deficit during growth stages of canola (Brassica napus L.) Amercan-Eurasian Journal of Agriculture and Environmental Science 2: 417422.

24. Soylu S, Topal A, Sade B, Akgun N, Gezgin S (2004) Yield and yield attributes of durum wheat genotypes as affected by BMO application in calcareous soils. An evaluation of major Turkish genotypes for BMO efficiency. Journal of Plant Nutrition 27: 1077-1106.

25. Steel RGD, Torrie JH, Dickey D (1997) Principles and procedures of Statistics, McGraw-Hill, USA.

26. Tripura CB, Sashidhar B, Podile AR (2005) Transgenic mineral phosphate solubilizing bacteria for improved agricultural productivity. In Microbial Diversity Current Perspectives and Potential Applications, I. K. International Pvt. Ltd, New Delhi, India

27. Walpola BC, Yoon MH (2012) Prospectus of phosphate solubilizing microorganisms and phosphorus availability in agricultural soils: A review. African Journal of Microbiology Research 6: 6600-6605.

28. Amanullah Asif M, Malhi SS, Khattak RA (2009) Effects of P-fertilizer source and plant density on growth and yield of maize in Northwestern Pakistan J Plant Nutr 32: 2080-2093.

29. Amanullah M, Zakirullah SK, Khalil (2010) Timing and rate of phosphorus application influence maize phenology, yield and profitability in Northwest Pakistan. Int. J. Plant Production 4: 281-292.

30. Amanullah, Khan MW (2011) Interactive effect of potassium and phosphorus on grain quality and profitability of sunflower in Northwest Pakistan. Pedosphere 21: $532-538$.

31. Vyas P, Gulati A (2009) Organic acid production in vitro and plant growth promotion in maize under controlled environment by phosphate-solubilizing fluorescent Pseudomonas. BMC Microbiology. 9: 174.

32. Steel RGD, Torrie JH, Dicky DA (1997) Principles and procedures of statistics, a biometrical approach, 3rd Edn, McGraw Hill, Inc. Book Co, New York..

33. Mahmood TM, Maqsood TH, Awan, Sarwar R (2001) Effect of different levels of $\mathrm{N}$ and intra-row plant spacing on yield and yield components. Pakistan $\mathrm{J}$. Agric. Sci 38: 48-49.

34. Ogbomo KEL, Remison SU (2009) Growth and yield of maize as influenced by sowing date and poultry manure application. Not. Bot. Hort. Agrobot. Cluj 37: 199-203.

35. Hussain A (1991) Effect of different phosphorus application on the growth and yield behavior of maize. Sarhad J. Agric 27: 2 .

36. Rahimi A, Pouzesh H (2012) Effects of waste water and phosphorus on Physiological and morphological characteristics of barley in the Boyerahmad region of Iran. Annals of Biomass Research 3: 2745-2749.

37. Aziz T, Ullah S, Sattar A, Nasim M, Farooq M, et al. (2010) Nutrient availability and maize (Zea mays L.) growth in soil amended with organic manures Int. J. Agric. Biol. 4: 621-624.

38. Balochgharayi $\mathrm{H}$ (2011) Effect of phosphorus fertilizer on chemical and biomass properties of the corn crop. Sarhad J. Agric 27: 2.

39. Yazdani M, Bahmanyar MA, Pirdashti H, Esmaili MA (2009) Effect of phosphate solubilization microorganisms (PSM) and plant growth promoting rhizobacteria (PGPR) on yield and yield components of corn (Zea mays L). World Academy of Science, Engineering and Technol 4: 102.

40. Hameeda B, Rupela OP, Reddy G, Satyavani K (2006) Application of plant growth-promoting bacteria associated with composts and macro fauna for growth promotion of pearl millet (Pennisetum glaucum L.). Biol. Fertil. Soils 43: 221-227. 